\title{
A survey on murine gammaherpesvirus 68 in ticks collected in Slovakia
}

\author{
M. KÚDELOVÁ ${ }^{1}$, M. SLOVÁK², P. KABÁT ${ }^{3}$, T. DERKA ${ }^{4}$, B. ŠTEVOVE ${ }^{4}$ M. BOHUŠ5 ${ }^{5}$ M. VRBOVÁ ${ }^{3}$
}

\begin{abstract}
${ }^{1}$ Department of Viral Immunology, Institute of Virology, Biomedical Research Center Slovak Academy of Sciences, Dúbravská cesta 9, 84505 Bratislava, Slovak Republic; ${ }^{2}$ Institute of Zoology, Slovak Academy of Sciences, Bratislava, Slovak Republic; ${ }^{3}$ Department of Microbiology and Virology, ${ }^{4}$ Department of Ecology and ${ }^{5}$ Department of Environmental Ecology, Faculty of Natural Sciences, Comenius University, Bratislava, Slovak Republic
\end{abstract}

Summary. - Murine gammaherpesvirus 68 (MHV-68) is a natural pathogen that infects murid rodents which serve as hosts for Dermacentor reticulatus and Ixodes ricinus ticks. For the first time, MHV-68 was detected in immature I. ricinus ticks feeding on lizards trapped in Slovakia. Later on, MHV-68 infection was detected in D. reticulatus and Haemaphysalis concinna ticks collected on vegetation, which supported the idea that ticks can acquire the virus from feeding on infected hosts. Here, we report MHV-68 infection, which was detected by nested PCR, in D. reticulatus and I. ricinus adult ticks and I. ricinus nymphs collected in five geographically isolated localities, in west, southwest, south and central Slovakia. Viral incidence in ticks was 46.7\% (121/259) without considering the season, site of collection and tick species and their life stage. MHV-68 infection was detected in all five localities investigated and in both tick species. Here, for the first time, we report MHV-68 infection in I. ricinus nymphs collected from the vegetation. The finding of virus in ticks from five separated localities suggested that ticks became infected with MHV-68 via feeding on infected rodents; thus, this virus might be a newfound natural pathogen in ticks.

Keywords: murine gammaherpesvirus 68; Dermacentor reticulatus ticks; Ixodes ricinus ticks; nested PCR; Slovakia

\section{Introduction}

Hard ticks are obligate hematophagous ectoparasites of wild and domestic animals and humans that most notably impact global health by transmitting disease-causing pathogens, including viruses. In Europe, there are two important hard tick spp., Dermacentor and Ixodes (Acari: Ixodidae), which act as important arthropod vectors and reservoirs for a series of pathogens such as bacteria (e.g., Rickettsia spp., Coxiella burnetii, Anaplasma phagocytophilum, Ehrlichia spp., Borrelia burgdorferi sensu lato, Francisella tularensis), protozoa (e.g.Babesia spp.) (Labuda and Nuttall, 2004, Estrada-Peña et al., 1999; Reye et al., 2013; Baneth, 2014) and viruses (e.g., tickborne meningoencephalitis virus, Colorado tick fever virus, Crimean-Congo haemorrhagic fever virus) (Estrada-Peña and

E-mail: virukude@savba.sk; phone: +421-2-59302434.

Abbreviations: MHV-68 = murine gammaherpesvirus 68 de la Fuente, 2014). I. ricinus ticks are a widely distributed tick species in Europe, including Slovakia (Černý, 1972), and they cause human and animal tick-borne diseases of medical and veterinary importance, such as tick-borne encephalitis, Lyme disease, anaplasmosis, and babesiosis. D. reticulatus Fabricius 1794, the three-host meadow tick that parasitizes primarily wild and domestic mammals and, infrequently, humans, is considered as the second most significant reservoir and vector of numerous pathogens causing bacterial, protozoal, rickettsial and viral diseases in its hosts. In Slovakia, the $D$. reticulatus tick had a focal distribution in Slovakia in the past (Nosek, 1972), occurring mainly in the southwest and southeast along the Morava, Danube and Latorica Rivers. Of late, D. reticulatus has extended its former geographical distribution in Slovakia by at least $200 \mathrm{~km}$ further to the North and by approximately $300 \mathrm{~m}$ into higher altitudes up to $520 \mathrm{~m}$ above sea level (Bullová et al., 2009).

Rodents play a role in the enzootic cycles of nonviral pathogens (Rickettsia spp., Ehrlichia spp., Francisella tula- 
rensis, and Coxiella burnetii) and viruses (e.g. hantaviruses, tick-borne encephalitis virus, MHV-68, and lymphocytic choriomeningitis virus). Thus, the rodents are important reservoirs for these pathogens (Burri et al., 2014). Apodemus spp. mice and Myodes glareolus exhibit infections with numerous tick-borne pathogens from the ticks that infest them. The most extensively characterized viruses that have rodent hosts in the family Muridae are the members of the family Herpesviridae. Murine gammaherpesvirus 68 (abbreviated as MHV-68 or $\gamma \mathrm{HV} 68$; the species Murid herpesvirus $4(\mathrm{MuHV}-4))$, classified in the genus Rhadinovirus of the subfamily Gammaherpesvirinae (Virgin et al., 1997), was originally isolated from bank voles (M. glareolus) (Blaškovič et al., 1980). Among murid rodents, MHV-68 spreads via intranasal routes and through host body fluids, such as saliva, urine, tears and breast milk (Rašlová et al., 2001). During acute respiratory infection in the host, it spreads from the lungs via the bloodstream to the spleen and bone marrow and via the lymphatics to the mediastinal lymph nodes. The virus causes a lifelong latent infection that may lead to lymphoproliferative disorders and tumor development. During latency, virus reactivation may occur, resulting in repeated lytic infection and further virus spread (Rajčáni et al., 1985; Nash et al., 2001, Rajčáni and Kúdelová, 2007).

In 2011, Ficová et al. (2011) have reported the first data on MHV-68 infection in $1.8 \%$ of immature I. ricinus ticks (15/799) infesting green lizards, which supports the idea that ticks can acquire the virus from feeding on infected hosts. Kúdelová et al. (2015) detected MHV-68 infection in approximately $40 \%(125 / 312)$ and $23.3 \%(28 / 120)$ of $D$. reticulatus adults collected in Vojka and Gabčíkovo, near the Danube River, in April 2014. Thereto, an examination of the salivary glands, intestines and ovaries of $D$. reticulatus ticks identified live MHV-68 capable of replication in mammalian cells, and thus suggesting that MHV-68 could meet some of criteria necessary for its recognition as arbovirus. However, little is known about the ecology of this virus in ticks. In this study, we assessed MHV-68 occurrence in D. reticulatus and $I$. ricinus ticks collected in five geographically separated localities of Slovakia using nested PCR.

\section{Materials and Methods}

Study sites. The ticks were collected in five localities of Slovakia. Four study sites, Vysoká pri Morave (near the Morava River) ( $\left.48^{\circ} 19^{\prime} 50.51^{\prime \prime} \mathrm{N}, 16^{\circ} 54^{\prime} 15.38^{\prime \prime E}\right)$, Vojka nad Dunajom (475ㅇ' $35^{\prime \prime} \mathrm{N}$, $17^{\circ} 22^{\prime} 50^{\prime \prime} \mathrm{E}$ ), Gabčíkovo ( $\left.47^{\circ} 54^{\prime} 00^{\prime \prime} \mathrm{N}, 17^{\circ} 35^{\prime} 00^{\prime \prime} \mathrm{E}\right)$, and Komárno $\left(47^{\circ} 45^{\prime} 48^{\prime \prime} \mathrm{N} 18^{\circ} 07^{\prime} 42^{\prime \prime} \mathrm{E}\right)$ are located at $\sim 145 \mathrm{~m}, 122 \mathrm{~m}, 114 \mathrm{~m}$, and $112 \mathrm{~m}$ above sea level, respectively. The fifth study site, near the town of Banská Štiavnica ( $\left.48^{\circ} 27^{\prime} 32^{\prime \prime N} 18^{\circ} 53^{\prime} 32^{\prime \prime}\right)$, is located at $\sim 621 \mathrm{~m}$ above sea level in the basin at the middle of the protected landscape area Štiavnické vrchy.
Sample collection. The study group of 259 ticks consisted of 247 adults of $D$. reticulatus $(\mathrm{n}=230)$ and I. ricinus $(\mathrm{n}=17)$ and 12 nymphs of $I$. ricinus collected over the vegetation in five localities of Slovakia in May $(\mathrm{n}=191)$ and September $(\mathrm{n}=68) 2014$ (Table 1).

DNA isolation from ticks. The DNA of all ticks was individually isolated using method described earlier (Kúdelová et al., 2015). As negative controls DNA samples of known negative D. reticulatus and $I$. ricinus tick from a tick colony were used.

Detection of MHV-68 DNA in ticks by PCR. Tick DNA samples were tested for the presence of MHV- 68 by nested PCR described earlier (Kúdelová et al., 2015), which targets the ORF 50 gene of MHV-68 (Acc. No. AF105037). The sequences of the outer PCR primers employed were ORF50/F1:5'-AACTGGAACTCTTCT GTGGC-3' and ORF50/R1:5'-GGCCGCAGACATTTAATGAC-3', which amplified a $586 \mathrm{bp}$ product. The sequences of inner primers were ORF50/F2:5'-CCCCAATGGTTCATAAGTGG-3' and ORF50/ R2: 5'-ATCAGCACGCCATCAACATC-3'), which amplified a 382 bp product. As a positive control, either DNA of MHV-68 BAC or virion MHV-68 DNA purified according to Rašlová et al. (2001) was used. PCR mixture without template served as an additional negative control. The nested PCR products were resolved on a $1.5 \%$ agarose gel stained by Goldview nucleic acid stain HGV-II (Beijing SBS Genetech, China).

Sequencing analysis. The nested PCR products of five and four randomly chosen adult $D$. reticulatus ticks (three from Gabčíkovo and two from Komárno) and I. ricinus ticks (from Banská Štiavnica) were purified using the PCR Clean-up system (Promega, USA) and commercially sequenced on both strands (BITCET) and compared with the MHV-68 ORF50 sequence according to the BLAST software (www.ncbi.nlm.nih.gov/blast).

Statistical analysis. A statistical analysis was conducted using the chi-square test and Past version 2.17b software (Hammer et al., 2001). The analysis examined the differences in virus occurrence between $D$. reticulatus and $I$. ricinus ticks. A $p$-value $<0.05$ was considered significant.

\section{Results}

We detected 121 ticks carrying MHV-68 DNA in a total of 259 ticks collected in five localities of Slovakia. Ignoring collection season, tick species, and life stage, viral incidence in ticks was $46.7 \%$ (Table 1). Viral incidence in D. reticulatus adults was $30.3 \%$ in a group of 132 ticks from Gabčíkovo (Fig. 1a: lanes 2-4, 6-9, and 12-15), 53.3\% in a group of 30 ticks from Komárno, $65.5 \%$ in a group of 28 ticks from Vojka nad Dunajom (data not shown), and $62.5 \%$ in a group of 40 ticks from Vysoká pri Morave (data not shown), respectively. Furthermore, viral incidence in I. ricinus ticks was $81.5 \%$ in a group of 17 adults from Banská Štiavnica (Fig. 1ba: lanes 1, 2, 4-10, 12 and Fig. $1 \mathrm{~b} b$ : lanes $1-3,5)$ and $25 \%$ in a group of 12 nymphs from Vysoká pri Morave (Fig. 1c: lanes 3, 5, 6), 
Table 1. Detection of MHV-68 in D. reticulatus and I. ricinus ticks collected in five localities of Slovakia in the year 2014

\begin{tabular}{|c|c|c|c|c|}
\hline Locality/altitude & Tick species & Time of collection & $\begin{array}{c}\text { Number } \\
\text { of MHV-68 } \\
\text { positive/tested ticks }\end{array}$ & $\begin{array}{c}\text { Virus } \\
\text { incidence } \\
(\%)\end{array}$ \\
\hline Vysoká pri Morave/145 m & D. reticulatus ${ }^{\mathrm{a}}$ & September & $25 / 40$ & 62.5 \\
\hline Vysoká pri Morave/145 m & I. ricinus $\mathrm{s}^{\mathrm{sN}}$ & May & $3 / 12$ & 25.0 \\
\hline Vojka nad Dunajom/122 m & D. reticulatus ${ }^{\mathrm{a}}$ & October & $23 / 28$ & 82.1 \\
\hline Gabčíkovo/112 m & D. reticulatus ${ }^{\mathrm{s}}$ & May & $40 / 132$ & 30.3 \\
\hline Komárno /114 m & D. reticulatus & April & $16 / 30$ & 53.3 \\
\hline Banská Štiavnica/621 m & I. ricinus $\mathrm{s}^{\mathrm{s}}$ & April & $14 / 17$ & 82.3 \\
\hline Total & & & $121 / 259$ & 46.7 \\
\hline
\end{tabular}

Notes: sspring, autumn, ${ }^{\mathrm{N}}$ nymph.

(a)

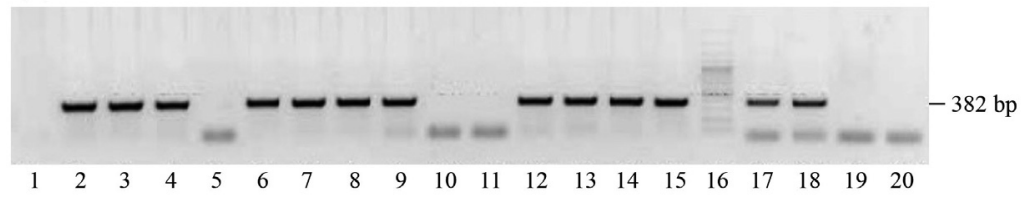

(b) $a$

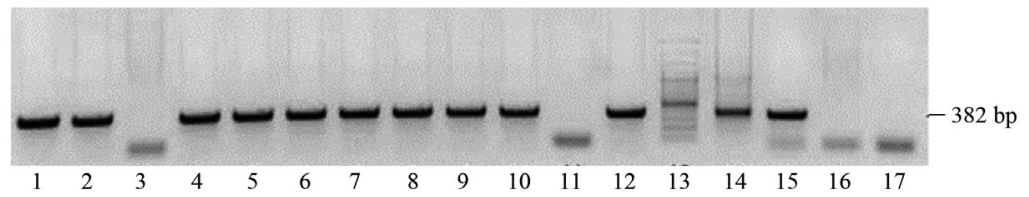

(b) $b$

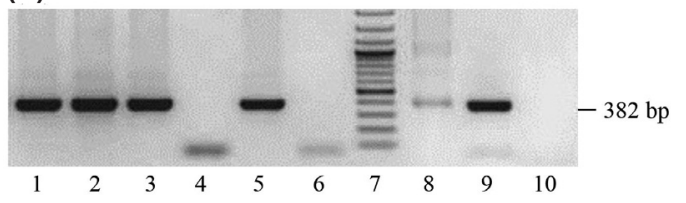

(c)

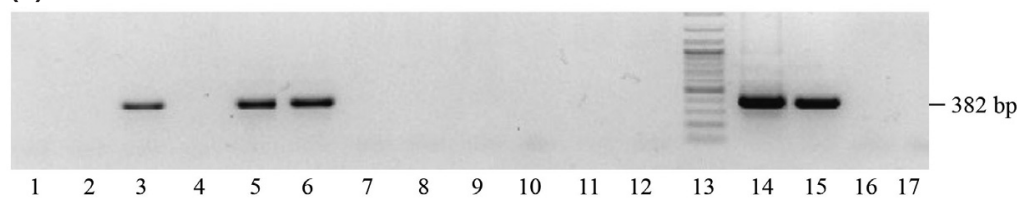

Fig. 1

Detection of MHV-68 in D. reticulatus and I. ricinus ticks collected in five localities of Slovakia using nested PCR

(a) Lanes 1-15: ticks Nos. 1-15; lane16: 100 bp ladder (Fermentas); lane17: MHV-68 BAC DNA (positive control), nested PCR; lane 18: MHV-68 BAC DNA (positive control), a single PCR with inner primers only; lane 19: negative control, nested PCR; lane 20: negative control, a single PCR with inner primers only; (b) $\boldsymbol{a}$ Lanes 1-12: ticks Nos. 1-12; lane 13: 100 bp ladder; lane 14: MHV-68 BAC DNA, a single PCR with inner primers only; lane 15: MHV-68 BAC DNA, nested PCR; lane16: negative control, a single PCR with inner primers only; lane 17: negative control, nested PCR; (b) b Lanes 1-5: ticks Nos. 13-17; lane 6: tick from colony; lane 7: 100 bp ladder; lane 8: MHV-68 BAC DNA, a single PCR with inner primers only; lane 9: MHV-68 BAC DNA, nested PCR; lane 10: negative control, nested PCR; (c) Lanes 1-12: ticks Nos. 1-12; lane 13: 100 bp ladder; lane 14: MHV-68 BAC DNA, a single PCR with inner primers only; lane 15: MHV-68 BAC DNA, nested PCR; lane 16: negative control, a single PCR with inner primers only; lane 17: negative control, nested PCR. Negative control - template replaced with sterile water.

respectively. Sequencing of the nested PCR products amplified from 5 D. reticulatus and 4 I. ricinus adults revealed
$100 \%$ identity with the corresponding ORF 50 sequence (data not shown). 


\section{Discussion}

Hard ticks D. reticulatus and I. ricinus often feed on small murid rodents, mainly of Apodemus spp. mice and M. glareolus, from which MHV-68 was originally isolated. Due to an ability to reactivate from latent infection, MHV-68 can exist for a relatively long time in the blood of murid rodents. After first confirmation of MHV-68 by molecular techniques in the blood of $34.4 \%$ of $M$. glareolus and A. flavicollis mice trapped in Slovakia (Klempa et al., 2001), several following studies have confirmed MHV-68 infection in immature $I$. ricinus ticks and $D$. reticulatus and $H$. concinna adults (Ficová et al., 2011; Kúdelová et al., 2015; Vrbová et al., 2016). In this study, we have confirmed MHV-68 in $46.7 \%$ of $D$. reticulatus and $I$. ricinus ticks collected in five geographically separated localities of Slovakia during a single year. The difference in viral incidence between $D$. reticulatus and I. ricinus ticks was not significant (45.2\% vs. 58.6\%), certainly due to the disbalanced numbers of tested ticks (130 vs. 29) $\left(\chi^{2}=1.8586, \mathrm{P}=0.172787\right.$ at $\left.\mathrm{p}<0.05\right)$. For the same reason, MHV-68 incidence strongly varied (from $30 \%$ to $82.3 \%$ ) in $D$. reticulatus ticks in individual localities. Comparing MHV-68 incidence in the largest group of this study, $132 \mathrm{D}$. reticulatus adults from Gabčíkovo (collected in May 2014), with a group of comparable size, 120 D. reticulatus adults (collected in Gabčíkovo in April 2014) have shown no significant difference $(30.3 \%$ vs. $23.3 \%)\left(\chi^{2}=1.5497, \mathrm{P}=0.213175\right.$ at $\mathrm{p}<0.05$ ) (Kúdelová et al., 2015). These results are consistent with the latest report on the presence of MHV-68 M3 gene transcripts in wild $D$. reticulatus ticks, supporting the idea that MHV-68 could be a newly-discovered arbovirus (Kúdelová et al., 2017).

Rodents are important hosts for Ixodes spp. ticks especially for larvae, to some extent for nymphs and adults (Bown et al., 2006; Zeidner et al., 2000). In this study, we have found a high overall $58.6 \%$ incidence of MHV-68 in a relatively small group of $29 \mathrm{I}$. ricinus ticks while $25 \%$ in the nymph group. It is apparent that MHV-68 incidence in I. ricinus ticks needs further exploring of statistically acceptable study groups. However, results are particularly interesting because I. ricinus ticks were collected at a relatively high altitude $\sim 621$ m above sea level (near Banská Štiavnica town). It correlates with recent data regarding the extension of areas and the shift in the altitudinal distribution limit and abundance of ticks in Europe including Slovakia (Dautel et al., 2006; Wielinga et al., 2006; Buczek et al., 2013; Lukáň et al., 2010; Hubálek and Rudolf, 2012). Finding of MHV-68 in I. ricinus nymphs infesting on lizards, which serve as particularly important host of immature I. ricinus ticks (Casher et al., 2002), has given rise to the hypothesis that MHV-68 might be vertically transmitted from nymphs to adults (Ficová et al., 2011). This study for the first time detected MHV-68 in immature I. ricinus ticks collected on vegetation, thus contributing to the most recent results of experimental vertical and horizontal transmission of MHV- 68 between I. ricinus ticks and their host - mouse and vice versa (Hajnická et al., 2017). In summary, the evidence of MHV-68 in both hard tick species and in five geographically separated localities of Slovakia investigated supports the hypothesis that ticks might facilitate MHV-68 circulation in nature. It is obvious that MHV-68 incidence in ticks strongly depends on many factors from which the density of virus-bearing host population seems to be the most important. One can hypothesize that other murid/murine gammaherpesviruses found in rodents such as A. flavicollis, A. sylvaticus, and Mus musculus (Blasdell et al., 2003; Ehlers et al., 2007; Hughes et al., 2010; Loh et al., 2011; Knowles et al., 2012) might occur in ticks feeding on these hosts.

Acknowledgments. This work was supported by the joint grant agency of the Slovak Ministry of Education and Slovak Academy of Sciences VEGA (\#2/087/17) and by the Slovak Research and Development Agency (\#APVV-15-474). The authors also acknowledge Prof. Koszinowski for providing the MHV-68 BAC.

\section{References}

Baneth G (2014): Tick-borne infections of animals and humans: a common ground. Int. J. Parasitol. 44, 591-598. https:// doi.org/10.1016/j.ijpara.2014.03.011

Blasdell K, McCracken C, Morris A, Nash AA, Begon M, Bennett M, Stewart JP (2003): The wood mouse is a natural host for Murid herpesvirus 4. J. Gen. Virol. 84, 111-113. https://doi.org/10.1099/vir.0.18731-0

Blaškovič D, Stančeková M, Svobodová J, Mistríková J (1980): Isolation of five strains of herpesviruses from two species of free-living small rodents. Acta Virol. 24, 468.

Bown KJ, Begon M, Bennett M, Birtles RJ, Burthe S, Lambin X, Telfer S, Woldehiwet Z, Ogden NH (2006): Sympatric Ixodes trianguliceps and Ixodes ricinus ticks feeding on field voles (Microtus agrestis): potential for increased risk of Anaplasma phagocytophilum in the United Kingdom. Vector Borne Zoonotic. Dis. 6, 404-410. https://doi. org/10.1089/vbz.2006.6.404

Buczek A, Bartosik K, Wiśniowski, Ł, Tomasiewicz K (2013): Changes in population abundance of adult Dermacentor reticulatus (Acari: Amblyommidae) in long-term investigations in eastern Poland. Ann. Agric. Environ. Med. 20, 269-272.

Bullová E, Lukáň M, Stanko M, Pet'ko B (2009): Spatial distribution of Dermacentor reticulatus tick in Slovakia in the beginning of the 21st century. Vet. Parazit. 165, 357-360. https://doi.org/10.1016/j.vetpar.2009.07.023

Burri C, Schumann O, Schumann C, Gern L (2014): Are Apodemus spp. mice and Myodes glareolus reservoirs for Borrelia miyamotoi, Candidatus Neoehrlichia mikurensis, Rick- 
ettsia helvetica, R. monacensis and Anaplasma phagocytophilum. Ticks and Tick-borne Dis. 5, 245-251. https:// doi.org/10.1016/j.ttbdis.2013.11.007

Casher LE, Lane RS, Barrett RH, Eisen L (2002): Relative importance of lizards and mammals as hosts for ixodid ticks in northern California. Exp. Appl. Acarol. 26,127-143. https://doi.org/10.1023/A:1020911306291

Černý V (1972): The tick fauna of Czechoslovakia. Folia Parasitol. 19, 87-92.

Dautel H, Dippel C, Oehme R, Hartelt K, Schettler E (2006): Evidence for an increased geographical distribution of Dermacentor reticulatus in Germany and detection of Rickettsia sp. RpA4. Inter. J. Med. Microbiol. 296 (Suppl. 40), 149-156. https://doi.org/10.1016/j. ijmm.2006.01.013

Ehlers B, Kuchler J, Yasmum N, Dural D, Voigt S, SchmidtChanasit J, Jäkel T, Matuschka FR, Richter D, Essbauer S, Hughes DJ, Summers C, Bennett M, Stewart JP, Ulrich RG (2007): Identification of novel rodent herpesviruses, including the first gammaherpesvirus of Mus musculus. J. Virol. 81, 8091-8100. https://doi.org/10.1128/ JVI.00255-07

Estrada-Peña A, Jongejan F (1999): Ticks feeding on humans: a review of records on human-biting Ixodoidea with special reference to pathogen transmission. Exp. Appl. Acarol. 23, 685-715. https://doi.org/10.1023/A:1006241108739

Estrada-Peña A, de la Fuente J (2014): The ecology of ticks and epidemiology of tick-borne viral diseases. Antiviral Res. 108, 104-112. https://doi.org/10.1016/j.antiviral.2014.05.016

Ficová M, Betáková T, Pančík P, Václav R, Prokop P, Halásová Z, Kúdelová M (2011): Molecular detection of murine herpesvirus 68 in ticks feeding on free-living reptiles. Microb. Ecol. 62, 862-867. https://doi.org/10.1007/ s00248-011-9907-7

Hajnická V, Kúdelová M, Štibrániová I, Slovák M, Bartíková P, Halásová Z, Pančík P, Belvončíková P, Vrbová M, Holíková V, Hails RS, Nuttall PA (2017): Tick-borne transmission of murine gammaherpesvirus 68. Front. Cell. Inf. Microbiol. 7, 458 https://doi.org/10.3389/fcimb.2017.00458

Hammer O, Harper DT, Ryan PD (2001): PAST: Paleontological Statistics software package for education and data analysis. Palaeontol. Electron 4, 9.

Hubálek Z, Rudolf I (2012): Tick-borne viruses in Europe. Parasitol. Res. 111, 9-36. https://doi.org/10.1007/s00436-0122910-1

Hughes DJ, Kipar A, Milligan SG, Cunningham C, Sanders M, Quail MA, Rajandream M-A, Stewart JP (2010): Characterization of a novel wood mouse virus related to murid herpesvirus 4. J. Gen.Virol. 9, 867-879. https:// doi.org/10.1099/vir.0.017327-0

Klempa B, Mačáková K, Labuda M, Kúdelová M (2001): Detection of murine herpesvirus (MHV) among free-living rodents by nested PCR. Infect. Dis. Rev. 3, 31-33.

Knowles SCL, Fenton A, Pedersen B, (2012): Epidemiology and fitness of wood mouse herpesvirus in a natural host population. J. Gen. Virol. 93, 2447-2456. https://doi. org/10.1099/vir.0.044826-0
Kúdelová M, Belvončíková P, Vrbová M, Kovalová A, Štibrániová I, Kocáková P, Slovák M, Špitalská E, Lapuníková B, Matúšková R, Šupolíková M (2015): Detection of Murine herpesvirus 68 (MHV-68) in Dermacentor reticulatus ticks, Microb. Ecol. 70, 785-794. https://doi.org/10.1007/ s00248-015-0622-7

Kúdelová $M$, Jánošová $M$, Vrbová $M$, Matúšková $R$, Slovák $M$, Belvončíková P (2017): Detection of transcripts and an infectious dose of murine gammaherpesvirus 68 in Dermacentor reticulatus Ticks. J. Infect. Dis. Ther. 5, 1-4.

Labuda M, Nuttall P (2004): Tick-borne viruses. Parasitology 129, 221-245. https://doi.org/10.1017/S0031182004005220

Loh J, Zhao G, Nelson ChA, Coder P, Droit L, Handley AS, Johnson LS, Vachharajanil P, Guzman H, Tesh RB, Wang D, Fremont DH, Virgin HW (2011): Identification and sequencing of a novel rodent gammaherpesvirus that establishes acute and latent infection in laboratory mice. J. Virol. 85, 2642-265. https://doi.org/10.1128/JVI.01661-10

Lukáň M, Bullová E, Pet́ko B (2010): Climate warming and tick-borne encephalitis, Slovakia. Emer. Infect. Dis. 16, 524-526. https://doi.org/10.3201/eid1603.081364

Nash AA, Dutia BM, Stewart JP, Davison AJ (2001): Natural history of murine gamma-herpesvirus infection. Philos. Trans. R. Soc. Lond. B. Biol Sci. 356, 569-579. https:// doi.org/10.1098/rstb.2000.0779

Nosek J (1972): The ecology and public health importance of Dermacentor marginatus and D. reticulatus ticks in Central Europe. Folia Parasitol. 19, 93-102.

Rajčáni J, Blaškovič D, Svobodová J, Čiampor F, Hučková D, Staneková D (1985): Pathogenesis of acute and persistent murineherpesvirus infection in mice. Acta Virol. 29, 51-60.

Rajčáni J, Kúdelová M (2007): Murid herpesvirus 4 (MHV-4): an animal model for human gammaherpesvirus research. In Minarovits J, Gonczol E, Valyi-Nagy T (Eds): Latency Strategies of Herpesviruses. Springer, Berlin, pp. 102-136.

Rašlová H, Berebbi M, Rajčáni J, Sarasin A, Matis J, Kúdelová M (2001): Susceptibility of mouse mammary glands to Murine gammaherpesvirus 72 (MHV-72) infection: evidence of MHV-72 transmission via breast milk. Microb. Pathog. 31, 47-58. https://doi.org/10.1006/ mpat.2001.0441

Reye AL, Stegniy V, Mishaeva NP, Velhin S, Hubschen JM, Ignatyev G, Muller CP (2013): Prevalence of tick-borne pathogens in Ixodes ricinus and Dermacentor reticulatus ticks from different geographical locations in Belarus. PLoSONE 8, e54476. https://doi.org/10.1371/journal.pone.0054476

Virgin HW IV, Latreille P, Wamsley P, Hallsworth K, Weck KE, Dal Canto AJ, Speck SH (1997): Complete sequence and genomic analysis of Murine gammaherpesvirus 68. J. Virol. 71, 5894-5904.

Vrbová M, Belvončíková $\mathrm{P}$, Kovalová $\mathrm{A}$, Matúšková R, Slovák $\mathrm{M}$, Kúdelová M (2016): Molecular detection of murine gammaherpesvirus 68 (MHV-68) in Haemaphysalis concinna ticks collected in Slovakia. Acta Virol. 60, 426-428. https://doi.org/10.4149/av $201604 \quad 426$ 
Wielinga PR, Gaasenbeek C, Fonville M, de Boer A, de Vries A, Dimmers W, Akkerhuis OP, Jagers G, Schouls LM, Borgsteede F, van der Giessen JW (2006): Longitudinal analysis of tick densities and Borrelia, Anaplasma, and Ehrlichia infections of Ixodes ricinus ticks in different habitat areas in The Netherlands. Appl. Environ. Microbiol. 72, 7594-7601. https://doi.org/10.1128/AEM.01851-06
Zeidner NS, Burkot TR, Massung R, Nicholson DMC, Rutherford JS, Biggerstaff BJ, Maupin GO (2000): Transmission of the agent of human granulocytic ehrlichiosis by Ixodes spinipalpis ticks: evidence of an enzootic cycle of dual infection with Borrelia burgdorferi in Northern Colorado. J. Infect. Dis. 182, 616-619. https://doi. $\underline{\operatorname{org} / 10.1086 / 315715}$ 